\title{
A Study of Spatial Narrative in the South Korean Movie "Parasite"
}

\author{
Shuquan Zhan ${ }^{1}$ Chao Liang ${ }^{2, *}$
}

\author{
${ }^{1}$ School of Foreign Languages, Xinhua College of Sun Yat-sen University, Guangzhou, Guangdong 511370, China \\ ${ }^{2}$ School of Marxism, Guangzhou College of Commerce, Guangzhou, Guangdong 511363, China \\ ${ }^{* *}$ Corresponding author. Email: 174592620@qq.com
}

\begin{abstract}
The South Korean movie "Parasite" won four awards in the 92nd Oscars, including the best film award, creating a miracle in the history of South Korean movies. This paper analyzes three layers of the physical space of three families in the film, revealing its postmodern spacial narrative structure. Through interpretation of the unique spatial image of "slope road", the paper fully demonstrates the rise and fall of Kim family's social status, and hope and despair of their mental journey. Through reconstructing the cruel struggle between people at the bottom of the society and their gratitude to the upper class, the paper exposes the collective unconsciousness of the lower class to the deep root of their plight and the fact that their struggle and resistance will inevitably lose the focus. On the basis of comparing the living space of different social strata and presenting the futile struggle of the lower class among different spaces, the film criticizes the social reality of the serious polarization between the rich and the poor in South Korea, and tries to arouse the profound concern of the society for the living conditions of the lower class.
\end{abstract}

Keywords: "Parasite", narrative space, annular spatial narrative, spiritual space

\section{INTRODUCTION}

Marcus argues, "Different space settings highlight the role and expression of space in film narrative and infuse a series of space presentation in films with distinctive directivity and a deep implication."[1] With differentiated image styles, "Parasite" exhibits three spatial environments of two social classes: the semibasement space where the Kims were living, the basement where the former housekeeper couple of Moon-kwang hid and the luxurious villa of the wealthy Mr. Park. The film reveals the dogfight within the underclass for survival space and the profound contradiction between the upper and lower classes through a delicate depiction of three spaces, the movement of characters from space to space and the montage techniques of many spaces.

\section{TRIPLE NARRATIVE SPACES OF BINARY OPPOSITION}

"The visuality of narrative space of films as a recreated artistic space makes it share some commonness with other artistic spaces. The machine

*Fund: Reform of Teaching Mode of ESP Course English Movie Literature Under the Internet plus Perspective, Projects of Reform of Higher Education and Teaching, Xinhua College of Sun Yat-sen University, 2020 involvement of the space composition of films differs the narrative space of films from general artistic spaces and displays a unique spatial expressiveness."[2] The complex narrative space of the film "Parasite" bears rich communicative functions ranging from revealing the environment and context of the story to reflecting the theme and aesthetics and social relations. The narration of the film is interwoven and unfolded in and between the semi-basement, luxurious house and basement.

The first space is the semi-basement where the Kims live. Through a series of visual elements such as light, shadow and colors, the film displays the execrable living environment of the Kims. The rooms are cramped, the flush toilet at a high position and the walls shabby and yellowish. The entire home is gloomy and air-polluted. The Kims have to loop up to see the outside world. Drunken men just vomit and urinate outside their window. These images highlight and symbolize their humble living space and social status. Besides, the film starts to create the concept of parasitism from their attempt to gain a free access to cellphone signal. The stove grasshopper on the bread implies the image of parasites. And then fumigation was sprayed in via the window, as a result of which the whole family coughed and struggled in the smoke like pests. In the film, the semi-basement home reflects all 
sorts of difficulties they are faced with. They are eager to get away from it, but they are unable to achieve it .

The most important space in the film is the residence of Mr. Park. It's a villa with high-walls. Inside the wall is a well-cared garden. There are large French windows in the house. The space of the rooms is broad and magnificent, forming a strong visual contrast with the dark and shabby semi-basement of the Kims. The huge French window of the living room is just like a large screen, playing a fantasy drama in which the four members of Kim family crawl into the luxurious villa one after another and then vanish from it one by one.

There is another parasite space in the basement of the villa. Compared with the semi-basement home of the Kims, the basement is almost isolated from the outside world and in nearly complete darkness. To Geun-sae, husband of the ex-housekeeper Moonkwang, it's a refuge and the last place he can depend on for survival. It is also a dark and closed space, a prison and grave for the body and a cage for the soul. Living here for long, one's body and mind would inevitably give out a rancid smell. When such a space is deprived of, the stink will surely spurt out, just as a Pandora's box is opened and anything might happen. Unknown to the wealthy owners, such a dark space exists under the villa for a long time, maintaining a subtle balance with the villa space.

Therefore, the film presents clearly vertical triple spaces. The wealthy space on the ground is decent and glamorous, symbolizing the perfect imagination of the underclass for a happy life. The poor space at the semibasement is wet and dirty, yet its occupants can still see sunshine and have hopes. The dark space under the ground is gloomy and horrible, standing for the thoroughly depraved and hopeless parasite world.

\section{ANNULAR SPATIAL NARRATIVE OF SLOPES}

Mieke Bal argues, "A way to understand the relationship of components is to divide sites into groups.'[3] The selection, combination and presentation of narrative spaces, namely the techniques of spatial narrative applied in films, can greatly promote the development of the plot and deepen the theme. "Undoubtedly, the innovation of annular narrative films in terms of profound contents and delicate structure is an exploration of film aesthetics. Its emergence has brought defamiliarized watching and aesthetic experiences to the audiences and reflected the situation and mental state of people in reality." [4] Slopes are spatial images with extremely rich interpretations in the film, which can refer to the slopes or stairs in reality and also symbolize the relative changes of the positions of figures in the same space. Slopes appear several times in the film, forming a complete string of story chains and intensifying the theme and extraordinary artistic expression of the film.

The first time Ki-woo went to work in the Park family, he was dressed refreshingly and walked along the stairs of his home onto the ground and then walked to the wealthy home along the upward slope. As a saying goes, human strives hard to move up. This spatial feature implies that Ki-woo, the hope of the entire family, was on an ascending direction in his life. Later, $\mathrm{Ki}$-jung and $\mathrm{Ki}$-taek successively walked up into the home of the Parks, which symbolizes the improvement of living conditions of the Kim family.

The slope appears for the second time when Moonkwang was framed up by the Kims, lost her job and left the wealthy family. Moon-kwang walked down the slope outside the villa, which forms a shocking visual contrast with the ascending scene of the Kims members. The two kinds of spatial placement reflect the relative changes of situations of the characters and their psychological changes, which lays a plot foundation for the subsequent conflict between the two families.

Later, Chung-sook followed Moon-kwang closely along the concealed winding passage of the kitchen into the dark and filthy basement where the two underclass families discovered the secret of each other and tussled violently. The shots of the film shift up and down the passage repeatedly, making a vivid depiction of the bloody struggle between the two underclass families for the limited survival space.

French thinker Henri Lefebvre argues, "The distinctive difference between social space and natural places is reflected in the fact that they are not juxtaposed simply, but more probably intervene, combine and overlay with each other--sometimes even conflict and collide with each other."[5] While the Kims and the couple of Moon-kwang were grappling with each other, the Parks suddenly returned at night. Instantly panic swept through all of them. Employing parallel montage, the film fully depicts the panic and nervousness of the Kims. The moment the Parks entered the living room, everything was quiet and still. Chung-sook pretended to wait upon the hostess calmly. Ki-taek hid himself in the air-raid shelter. Ki-woo hid away under the bed, and $\mathrm{Ki}$-jung lied still under a tea table. Some hours ago, they occupied the entire villa and enjoyed themselves. At this moment, they could do nothing but remain still on the floor. This contrast between the higher and lower spaces was set to leave a deep imprint in their mind. The spatial contrast between the Parks and the Kims clearly reveals that the alleged hope of the Kims is so humble and fragile in front of the Parks. As a result, the original so-called harmonious and co-existential parasitic relation became aggressively antagonistic. 
After that, Ki-woo, Ki-taek and Ki-jung escaped out of the wealthy family at night in the heavy rain. The movie gives a complete presentation of their escape through montage techniques, from the slope at the gate of the wealthy home to the streets and pedestrian overpass and finally to their home - the semibasement. Seeing the home flooded by rainwater, the Kims hurried to salvage their belongings from the muddy water. Even if Ki-jung sat on the flush toilet, she failed to stop the dung water from gushing out. The stink seems to penetrate through the screen and jump at the audiences. The close-up shot presents the miseries of the underclass to the audiences like a documentary. Their constantly sinking spatial changes coincide with the cruel reality of the family falling from their illusory peak of life to a miserable shame.

The next day, at the birthday party of the son of Mr. Park, the disgust displayed by Mr. Park towards the stink of Geun-sae completely provokes the strongest feelings of humiliation of Ki-taek as an underclass father. He stabbed Mr. Park on his chest with a knife. At this moment, the smell pulls Ki-taek and Geun-sae, two representatives of the underclass onto the same battle line and helps them reach a symbolic reconciliation and directly confront with the elites represented by Mr. Park. Ki-taek escaped into the underground through the stairs leading into the garage. This is the shortest one among all shots of slope space, yet it forebodes the further decline of the status of $\mathrm{Ki}$ taek from the semi-basement space to the total underground space. Ki-woo and his mother returned to their semi-basement home and began to build their new dream.

From the start of the movie when Ki-woo walked out of the semi-basement to the end of the movie when Ki-taek walked into the air-raid shelter, slopes form a complete close loop. This unconventional narrative structure links up singular narrative chains into a cyclic circle, providing the audiences with unlimited interpretations. The three independent spaces, originally paralleled, are connected by slopes. In this way, the concealed narrative foreshadows are presented one by one, which reveals the highly tacit internal connection between the deep meanings and narrative structure of the film. Slopes stand for the journey of their mind from hope to disillusion. Ordinary people crouching at the bottom of the society have no way out in the face of double blows from homogeneous competitions and the oppression from the upper-class. "Dangerous days are annular and have nowhere but to be destroyed."[6] Besides, the main narrative space of the film extends from a semi-basement to a villa and then to a basement, forming two levels of annular space with the slopes, which is a metaphor of the unbreakable class imprisonment and the barrenness of spiritual space of the underclass.

\section{UNFOCUSED SPIRITUAL SPACE}

"According to theories of spatial narrative, literary space is seen as a complex metaphor and semantic system and attention is paid to such forms of ideological expression as history and culture, national identity and state power, which thus endows the space with a strong meaning of social history and moral culture." [7] From the semi-basement to the luxurious villa, and then back to the semi-basement and to the underground shelter, behind the tragedy of the Kims is their unfocused spiritual space. The yearning of the Kims and the fight of the couple of Moon-kwang for luxurious space reflect the out-of-control desire and greed of the two families. It also reveals the collective unawareness of the underclass in South Korea with the substance of their fates.

If it is understandable that $\mathrm{Ki}$-woo disguised his identity to get the job as an English tutor for the wealthy family under the persuasion of his friend, then his desire swore when he made up a lie so that his younger sister could also get employed by the wealthy family. Ki-jung easily drove away the former driver of the Park family, which pushes the greed of the Kims to a more dangerous stage. In order to get rid of the former housekeeper Moon-kwang and let Chung-sook enter the wealthy home, greed drove the Kims crazy. The whole family worked together to put on a pungent satirical comedy. By applying parallel montage, the movie juxtaposed the framing rehearsal and deception scenes of the Kims. By applying crossed montage, the movie links up the seamless cooperation of the Kims in backstabbing Moon-kwang. The two kinds of montage techniques shift back and forth among the deception rehearsal of the Kims, their persuasion of the wealthy couple and their backstabbing Moon-kwang, creating a multi-dimensional time and space with a hectic pace and a tense atmosphere. The two montage techniques are crossed and combined to contrast and highlight each other and produce a strong artistic appeal, which fully exhibits the boundless desire and distorted humanity of the Kims and foreshadow their ultimate out-of-control desire and disillusion.

Furthermore, the two underclass families that harmed each other have never been able to realize the underlying cause behind their awkward situation. Geunsae hid himself in the basement for over four years and often addressed Mr. Park respectfully. Ki-taek was also grateful to Mr. Park and expressed regret on his murdering Mr. Park in the end. In their eyes, they seemed to co-exist perfectly with the Parks and it was the intervention of the opposite side that ruined their perfect plans. However, similar to the parasitic phenomena in the biosphere, the parasite and the host seem integrated as a whole superficially, yet in substance they are two kinds of independent life entities with desperate distinctions. 
When the owners of the villa are away, the Kims splash out as if they were the real owners of the villa and ascended to the upper-class. The son Ki-woo fancied marrying the daughter of the wealthy family as his wife and hired strangers to play the role of his parents at the wedding. The couple of Ki-taek even did not forget to evaluate the wealthy couple, "They are wealthy and kind-hearted." "They are kind because they are rich." In the novel A Woman on a Roof, three underclass repairmen working on the roof were ignored as they commented on a woman sunbathing on the roof of the neighbor building. This kind of cognition is nothing more than their wishful fantasy and a selfintoxicating spiritual opium, which reflects their limitation in the awareness of the environment they are in.

The mother Chung-sook was once an athlete who ever won athletic medals. The father ever started up a business and was good at driving. The son dreamed to be admitted into a renowned university and change his own social class. The daughter was gifted in art and proficient in computer skills. All members of the family are excellent, yet idle about and could only land a job through nepotism. Seemingly absurd and illogical, yet in fact it is a realistic portrayal of the South Korean society. Just as Ki-taek said in the story, "500 college graduates apply for the position of a driver." In South Korea, a country of monopoly capitalism, wealth is highly concentrated, which has resulted in class solidification. It is difficult for the underclass to cross the gap of class distinction however hard they try. The upper-class show little sympathy to the underclass, even if the underclass are struggling on the verge of collapse. Moreover, the former suppress the latter, visibly and invisibly all the time, just as the warning of Mr. Park, "Never cross the boundary." The luxurious space contains a power mechanism for discipline and punishment. Once the underclass cross the boundary, they will be forced to return to their original form and even fall into a more miserable situation.

The violent fight between the two underclass parasite families reveals the collective unconsciousness of the underclass of their own class dilemma. They can do nothing but harm each other to scramble for the limited survival space. They seem to enter "a space filled with illusion and imitation and a purely direct and superficial space".[8] "It seems that you lose your sense of distance completely and can no longer perceive the landscapes and volume and are involved in a superspace."[9] In face of the flowing and splitting of fragmentary space, the Kims are stuck in a strong sense of dislocation and cannot identify the direction or map their exact position or the class they are in. They have fallen into chaos and confusion and do not know what to do. Therefore, Ki-taek's murder of Mr. Park is simply an unorganized and symbolic resistance, which will never shake the edifice of the social classes in Korea at all.

\section{CONCLUSION}

The movie "Parasite" deeply reflects the social reality of South Korea behind the construction of multiple spaces and the complex spatial narrative. For people at the bottom of society, their illusory dream could not withstand the weight of reality. When their deception is exposed and their humble self-esteem is trampled, tragedies are unavoidable. However, what makes them more painful is that after the tragedy, nothing is changed in the society and their living space remains the same, if not worse. It's the core issue explored in the movie.

\section{References}

[1] Clare Cooper Marcus. House as a Mirror of Self: Exploring the Deeper Meaning of Home [M]. United States of America: Nicolas-Hays, 2006: 1

[2] Compiled by Zhang Hao, Feng Xiao. Film and TV Works Analysis Tutorial (The Part of Movies) [M]. National Defence Industry Press, 2008:203.

[3] Mieke Bal. Translated by Tan Junqiang. Narratology: Introduction to Narrative Theory [M]. China Social Sciences Press, 2003:49.

[4] Chen Ling. About Definition of Annular Narrative Films [J]. Film Literature, 2018, 1:35.

[5] Quoted from Zhu Liyuan. Contemporary Western Literary and Art Theories [M]. Shanghai: East China Normal University Press, 2005: 491.

[6] Mao Qi. On the Characteristics of Annular Narrative Structure of Films [J]. Film Literature, 2007, 7:31.

[7] Yang Mingming. Narrative Space of "Cossack" [J]. Foreign Literature Studies, 2015, 4:147.

[8] Homer, Sean. Trans. Sun Bin, et al. Fredric Jameson [M] Shanghai: Shanghai People's Press, 2004: 172.

[9] Jameson, Fredric. Postmodernism, or the Cultural Logic of Late Capitalism [M]. Durham: Duke Up, 1991: 227. 